\title{
NI LABVIEW KÉPFELDOLGOZÁSI ALGORITMUSOK ALKALMAZÁSA, ILLESZTÉSE IPARI ESZKÖZÖKHÖZ
}

\section{APPLICATION OF IMAGE PROCESSING METHODS IN NI LABVIEW AND ITS ADAPTATION TO INDUSTRIAL DEVICES}

\author{
Tóth Xénia Erzsébet ${ }^{1}$, Zilahi Krisztián László ${ }^{2}$ \\ Debreceni Egyetem, Müszaki Kar, Villamosmérnöki és Mechatronikai Tanszék, \\ 4028, Magyarország, Debrecen, Ótemetö utca, 2-4, \\ Itothxeniaerzs@gmail.com,.2imkrisztian@mailbox.unideb.hu
}

\begin{abstract}
In this paper we introduce a production process using different image processing methods. We made an NI LabVIEW application to help the control process of a Festo MPS sorting station. We describe the image processing methods that we used in LabVIEW, and with which we could replace the function of the different sensors. During the development of the system we have taken into consideration its integration to other, existing devices or production cells.
\end{abstract}

Keywords: LabVIEW, image process, PLC, color detect, edge detect

\section{Összefoglalás}

A cikkben bemutatunk egy korszerü, képfeldolgozási módszerek alkalmazásával segített gyártási folyamatot. Elkészítettünk egy NI LabVIEW alkalmazást, mely egy Festo MPS szortírozó munkaállomás vezérlésének kiegészítéséhez használtunk fel. Ismertetjük a LabVIEW-ban alkalmazott képfeldolgozási eljárásokat, illetve hogy ezek mely szenzorok által szolgáltatott információk kiváltására alkalmasak. A rendszer kialakításánál figyelembe vettük annak integrálhatóságát, hogy az meglévő eszközökhöz, gyártó cellákhoz is könnyen illeszthető legyen.

Kulcsszavak: LabVIEW, képfeldolgozás, PLC, szinfelismerés, éldeketálás

\section{Bevezetés, előzmények}

Az ipari folyamatok során, számos helyen alkalmaznak képfeldolgozási eszközöket, ezeket elsősorban minőség ellenőrzési célból használják. A mai modern eljárásoknak megfelelően ezek az algoritmusok a digitális képfeldolgozási alapokon nyugszanak. A képfeldolgozási módszerek - az informatikai rendszerek és a félvezetők gyártási technológiájának fejlödésének köszönhetően - egyre jobban elterjedtek, mi- vel biztosítani tudják az ipari környezetben a nagyon gyors és megbíztató termékellenőrzési folyamatokat [1].

A képfeldolgozási módszereknek nem kizárólag a minőség ellenőrzési folyamatok során lehet nagy jelentősége, mivel ezen alkalmazások flexibilitása - a képek nagy információ tartama és az eszköz (IP vagy webkamera) mobilitása miatt - lehetővé teszik például a munkadarabok, termékek felismerését, követését és megfelelö techno- 
lógia alkalmazásával a termékek azonosítását is [2].

Ebben a cikkben bemutatunk egy olyan speciális felhasználási példát, amelyben egy rugalmas gyártó cella (jelen esetben egy szortírozó állomás) funkciójának ellátása érdekében kiváltottuk az azon elhelyezett ipari szenzorokat (és azok jeleit) egy képfeldolgozási alkalmazással. A rendszer kialakításánál törekedtünk arra, hogy a gyártócella alapfeladatát maradéktalanul elássa, valamint azt kiegészítő funkciókkal láttuk el.

\section{Az alkalmazott gyártócella modell}

A tanulmány elkészítése során a Festo Kft. által forgalmazott szortírozó MPS (Modular Production System) állomást használtunk fel, mivel ezen az állomáson bemutatható a termékfelismerés, követés, valamint az osztályozási feladat is.

A szortírozó állomás (1. ábra) fö feladata, hogy különböző színü munkadarabokat válogasson szét, és raktározzon három csúszdára. A szállítószalag elején a munkadarab jelenlétének észlelése után, a termék a szalagon továbbításra kerül a detektáló részhez. A munkadarab színének megállapítását követően (piros, fekete, ezüst) a szalagon elhelyezett stopper-munkahenger továbbengedi azt, és a megfelelő pneumatikus terelöhenger müködtetésével a kívánt csúszdára juttatja.

A cella vezérlése egy programozható logikai vezérlővel (PLC) történik, mely jelen esetben WAGO PFC100-as típusú. A programkódot CoDeSys v2.3-as környezetben készítettük el, strukturált szöveges programnyelven.

A rendszer bővítése, továbbfejlesztése során a PLC programját úgy készítettük el, mintha a bemenetek tényleges fizikai inputok lennének (az állomáson korábban megtalálható szenzorok szerint). Ezeket az információkat a program kizárólag a képfeldolgozó egységtől gyűjti be, a korábbi szenzorok használta helyett.

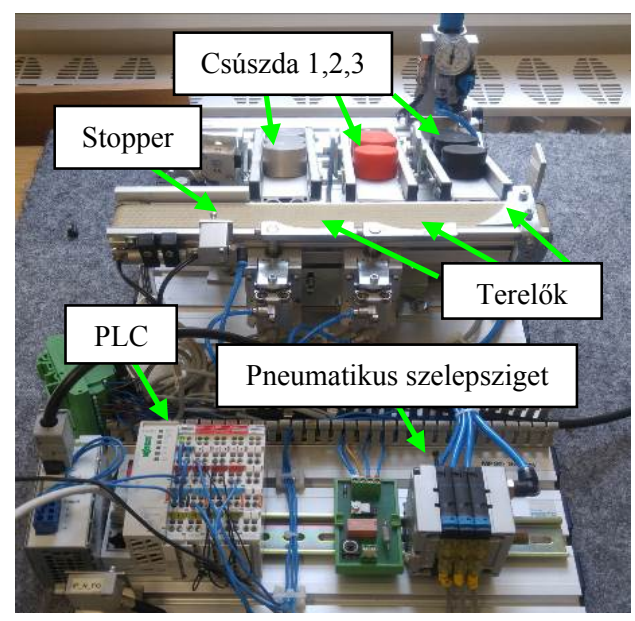

1. ábra. A szortírozó munkaállomás

\section{Képfeldolgozás}

A szortírozó munkaállomást kiegészítettük egy képfeldolgozásért felelős LabVIEW alkalmazással (2. ábra), amely az állomásra irányított webkamera segítségével képes kiváltani az állomáson gyárilag elhelyezett szenzorok jeleit. A képfeldolgozási metódusokat a szenzorok eredeti funkciójának megfelelően választottuk ki.

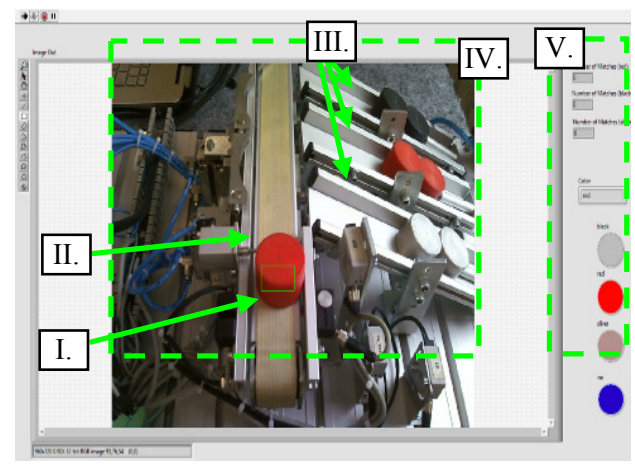

2. ábra. Az elkészitett LabVIEW alkalmazás front panelje

A képfeldolgozás során valós időben (real-time) elemeztük a webkamera által szolgáltatott képet. A kamera és a megjelenítendő kép tulajdonságai a Vision 
Acquistion funkcióblokk segítségével konfigurálhatóak.

A fejlesztőkörnyezetbe integrált Vision Assistant használatával elöre definiált képfeldolgozási eljárásokat lehet igény szerint alkalmazni.

\subsection{Forma detektálás}

A forma felismerő algoritmus (Geometric Matching) a felhasználó által betanított minta szerinti éldetektáláson alapul. Jelen esetben ezt az eljárást a gyártósorra érkezö új munkadarab formájának felismerésére használjuk (elöre megadott egyféle alak detektálására, tehát színtől függetlenül, a jelenlét érzékelésére), melynek szerepét eredetileg az MPS állomáson egy tárgyreflexiós optikai szenzor töltötte be. A zavaró hatások elkerülése érdekében a felismerési tartományt a futószalag elejére korlátoztuk (2. ábra, I.). Amikor az alkalmazás egyezést talál, azt egy belső logikai változóban tárolja.

\subsection{Színmeghatározás}

A munkadarabok színmeghatározása az állomáson korábban két érzékelővel történt.

1. táblázat. A munkadarab szinérzékelésének logikai összefüggései

\begin{tabular}{|c|c|c|}
\hline \multirow{2}{*}{$\begin{array}{c}\text { Munkadarab } \\
\text { típusa }\end{array}$} & \multicolumn{2}{|c|}{ Szenzor típus } \\
\cline { 2 - 3 } & Induktív & Optikai \\
\hline Piros & nem érzékel & érzékel \\
\hline Fekete & nem érzékel & nem érzékel \\
\hline Ezüst/Fém & érzékel & független \\
\hline
\end{tabular}

Az ezüst munkadarab fémből készült, így az egy induktív jeladóval volt felismerhetö, míg a piros és fekete munkadarabok színe egy állítható érzékenységü tárgyreflexiós optikai érzékelővel volt megállapítható. Az érzékelés logikai összefüggései az 1. táblázatban láthatóak.

A Color Classification funkció egy adott helyen, jelen esetben a stopper elötti területen (2. ábra, II.) vizsgálja az elöre betanított minták alapján, hogy milyen szín található ott. Ehhez színenként (class) több min- tát (sample) szükséges megadni, ezek beállításai (intenzitás, finomság, stb.) módosíthatók. A front panelen opcionálisan megjeleníthető az ebben a tartományban lévő színösszetétel hisztogramja. Így látható a képet felépítő képpontok számának eloszlása valamennyi színerösségi szinten. A hisztogramon a színekhez tartozó árnyékok a bal oldalon, a középtónusok középen, és a csúcsfények a jobb oldalon láthatóak.

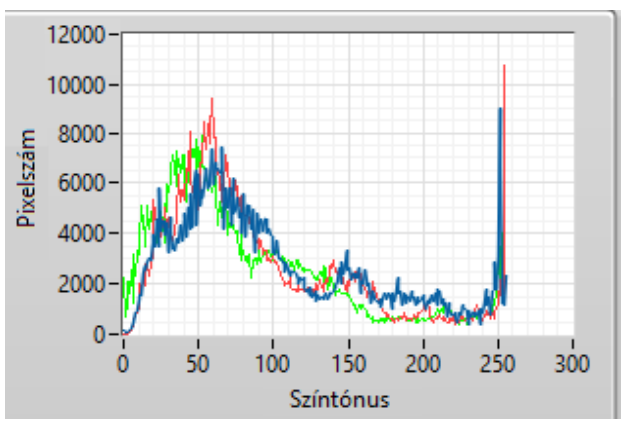

3. ábra. $A$ vizsgált terület $R G B$ hisztogramja

A hisztogramon megfigyelhetö (3. ábra), hogy az egyes RGB komponensek milyen színintenzitással ( 8 bites felbontás), azaz pixelszámmal jelennek meg a vizsgált tartományban (2. ábra, II.), és ezt az értéket összehasonlítva az elöre definiált mintákkal a program képes eldönteni, hogy milyen színủ az adott munkadarab. A munkadarab színének megfelelöen az 1. táblázatban foglaltak szerinti jeleket, változókat állítottunk elö.

\subsection{Színfelismerés}

A munkadarabok lecsúszását érzékelő kétutas optokapu kiváltására egy színfelismerő metódust használtunk. Ez a funkció egy előre definiált szín helyének meghatározására képes egy adott tartományon belül (2. ábra, III), ami jelen esetben az megfelelő színhez rendelt csúszda eleje. A színek helyének meghatározása a Visual Assistantben a Color Location alkalmazással lehetséges, egyenként a színek mintavételezéses betanítása után. 


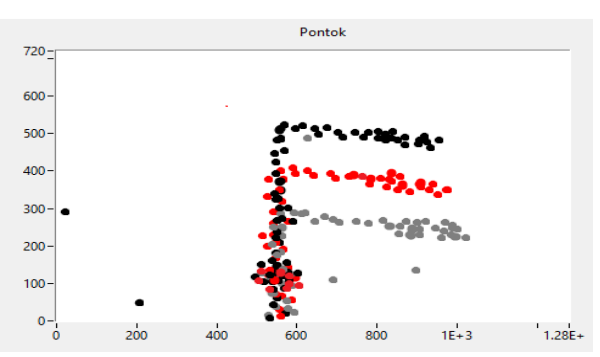

4. ábra. Színes objektumok követése

Ez az eljárás a tartományok kibővítésével (teljes kamerakép, 2. ábra, IV.) meghatározott színü objektumok követésére is lehetőséget ad. A front panelen folyamatosan frissülve megjelenítésre kerül a betanított 3 féle színü munkadarab helyzete. Ezt egy általunk megírt MathScript plottolja ki egy grafikonra (4. ábra).

\section{Kommunikáció a rendszeren belül}

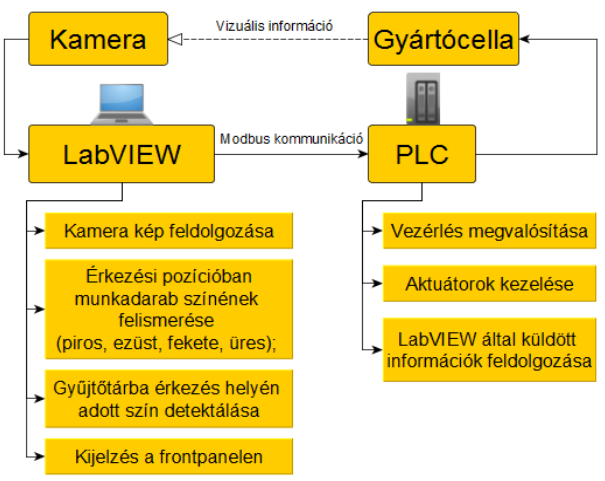

5. ábra. A rendszer blokkdiagramja

A rendszeren belüli kommunikáció (5. ábra) egy Ethernet alapú, Modbus TCP/IP ipari kommunikációs protokollon történik. A hálózaton belül a PLC tölti be a Modbus Szerver (Slave) szerepét, így generál egy valós idejü adatbázist. Az adatbázisban szereplő megfelelő változók értékeinek beírását, valamint olvasását a PLC is végezheti vagy a PC-n futó LabVIEW alkalmazás. A LabVIEW, mint Modbus Kliens (Master) tud csatlakozni a szerverhez [3].

\section{5. Összegzés, következtetések}

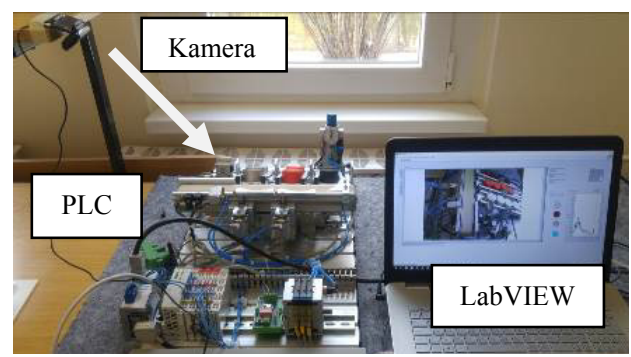

6. ábra. Az összeállitott rendszer

A tanulmány során ismertettük a képfeldolgozás jelentőségét a gyártási folyamatok szempontjából. Létrehoztunk egy rendszert, amelyen keresztül bemutattunk képfeldolgozási módszereket, mellyel kiváltottuk az eredetileg használt szenzorokat [4]. Az elkészített alkalmazás meglévő rendszerekbe való integrálása a mai modern gyártási trendnek megfelelő rugalmas szenzorhálózatot eredményezhet.

A LabVIEW alkalmazás a képfeldolgozás mellett a felhasználói interfész szerepét is betölti (2. ábra, IV-V.), illetve lehetőséget ad akár távoli felügyeleti rendszer kialakítására is (webszerver). További felhasználási, fejlesztési lehetőségek közé tartozik hö kamera, sztereo kamera integrálása, valamint akár egy önkalibrálású rendszer létrehozása is.

\section{Szakirodalmi hivatkozások}

[1] A. Barth, R. Herpers, M. Gressnich: Realtime applicable visual quality control in industrial line production, Proc. IEEE Int. Conf. ASME, 2007, 1-6.

[2] L. Stroppa, N. Rodrigues, P. Leitao, N. Paone: Quality control agents for adaptive visual inspection in production lines, Proc. IEEE Int. Conf. IECON, 2012, 4354-4359.

[3] Ajtonyi István: Ipari kommunikációs rendszerek I. 1. kötet. kiadó: AUT-INFO Kiadó, Miskolc, 2008. 431. ISBN szám: 9789630658133

[4] Az elkészített rendszert bemutató videó: https://youtu.be/kJ3QgXR0ld0 Megtekintve: 2017.02.27. 